\title{
STUDI OPTIMASI POLA TANAM DAERAH IRIGASI GONG GANG KECAMATAN PARANG KABUPATEN MAGETAN
}

\section{Optimization Study of Cropping Area Gong Gang Irrigated of Parang Districts Magetan Region}

\author{
Ernawan Setyono $^{1}$, Safik Mucharom ${ }^{2}$ \\ 1,2 Jurusan Teknik Sipil, Fakultas Teknik, Universitas Muhammadiyah Malang \\ J1. Raya Tlogomas No.246, Malang (0341) 464318
}

\begin{abstract}
Along with the increasing population growth, the need for food also increased. To meet that need for optimization studies of the factors that influence spatial patterns of planting in order to increase the volume of food production. Determination of the cropping pattern that will be used after the first known dependable flow and water requirements. Through the design cropping pattern is expected cropping intensity can be enhanced and existing water sources can be used optimally. linear programming used in this optimization study using QM for Windows 4 software. The most optimal results from the optimization that has been done is an alternative was began on November cropping patterns : rice-palawija-sugarcane season crops beginning 1st week of November, profits amounted to $R p$ 106.729.700.000 to the area that can be cultivated for the planting season I: Rice $=1990$ ha, palawija $=307$ ha sugarcane $=89$ ha, planting season II: Rice $=1990$ ha, palawija $=307$ ha sugarcane $=89$ ha, and planting season III: Rice $=258,2753$ ha Palawija $=2038,725$ ha, sugarcane $=89$ ha.
\end{abstract}

Keywords : dependable flow, water requirements, design cropping

\begin{abstract}
Abstrak
Seiring dengan pertumbuhan penduduk yang semakin meningkat, maka kebutuhan panganpun meningkat . Untuk memenuhi hal tersebut perlu adanya studi optimasi terhadap faktor-faktor yang mempengaruhi pola tata tanam guna peningkatan volume produksi pangan. Penentuan pola tanam yang akan di pakai setelah terlebih dahulu diketahui debit andalan dan kebutuhan air. Melalui rancangan pola tanam ini diharapkan intensitas tanam dapat ditingkatkan dan sumber air yang ada dapat dimanfaatkan secara optimal. Linier programming yang dipakai dalam studi optimasi ini menggunakan software QM for Windows 4. Hasil yang paling optimal dari optimasi yang sudah dilakukan adalah alternative pola tanam yang dimulai bulan November 1: Padi-palawija-tebu awal musim tanam minggu ke-1 bulan November keuntungan yang diperoleh sebesar Rp 106.729.700.000 dengan luasan yang dapat ditanami untuk musim tanam I: Padi $=1990$ ha, palawija 307, tebu $=89$ ha, musim tanam II : Padi $=1990$ ha, palawija $=307$, tebu $=89$ ha, dan musim tanam III $:$ Padi $=258,2753$ ha Palawija $=2038,725$ ha, tebu $=$ 89 ha.
\end{abstract}

Kata kunci : Debit andalan, Kebutuhan Air, Pola Tanam

\section{PENDAHULUAN}

Penyimpangan dalam pelaksanaan tanam yang diterapkan seringkali tidak sesuai dengan pola tanam rencana atau rencana tanam detail yang diusulkan. Kasus ini umumnya sering terjadi disaat musim kemarau petani lebih banyak menanam jagung dari pada tanaman padi, sehingga tanaman jagung yang ditanam melebihi dari luas yang direncanakan. Kondisi semacam ini tentunya akan berpengaruh terhadap pertumbuhan dari tanaman padi itu sendiri yang pada akhirnya akan menyebabkan hasil produksi yang kurang maksimal. Hal ini akan menyebabkan debit air yang tersedia tidak dapat mencukupi kebutuhan air irigasi Bdan berakibat pemberian air tidak merata (Soetopo, 2009). Indonesia merupakan negara agraris sehingga sangat wajar dilakukan pembangunan di bidang pertanian yang menjadi prioritas utama dalam agenda pembangunan nasional dan memberikan komitmen tinggi terhadap pembangunan ketahanan pangan. Hal itu 
sesuai dengan tuntutan UU No.7 tahun 1996 tentang pangan yaitu ketahanan pangan merupakan kewajiban pemerintah bersama masyarakat (Partowijoto, 2003). Ketahanan pangan diartikan sebagai kondisi terpenuhinya pangan bagi rumah tangga yang tercermin dari tersedianya pangan yang cukup, baik dalam jumlah maupun mutunya, aman dan merata, serta terjangkau . Di Kabupaten Magetan terutama di bagian selatan yaitu di Kecamatan Poncol, Ngariboyo dan Lembeyan dengan jumlah penduduk \pm 108.000 jiwa ( dalam tahun 2008 ) sebagian besar masyarakatnya hidup dari hasil pertanian. Didaerah tersebut keadaan lahannya sangat gersang dan tandus, dimana pada musim kemarau sangat kekurangan air. Oleh karena itu, Tujuan dari penelitian ini yaitu untuk mendapatkan pola tanam yang terbaik, sehingga pembagian debit air irigasi yang tersedia di daerah irigasi khususnya Daerah Irigasi Gong Gang dapat dilakukan secara optimal yaitu sesuai dengan luas lahan dan rencana pola tanam yang ada .

Tujuan dari penelitian ini adalah untuk mendapatkan sistem pola tanam dengan membandingkan kebutuhan air eksisting dengan kebutuhan air rencana. Selain itu, sebagai salah satu indikator yang nantinya diharapkan agar bisa di kembangkan dengan metode perencanaan Pola tanam yang lebih terpadu.

Manfaat dari penelitian ini adalah memberikan sebuah wawasan bagaimana mengelola sumber daya air termasuk di dalamnya dalam hal merencanakan suatu model optimalisasi pola tanam. Sedangkan bagi Masyarakat adalah Dapat memberikan nilai ekonomis yang lebih dengan terciptanya produk pertanian yang variatif dan unggul melalui terciptanya jaringan irigasi dan sistem pola tanam yang baru.

\section{Irigasi}

Irigasi ialah usaha untuk memperoleh air yang menggunakan bangunan dan saluran buatan untuk keperluan penunjang produksi pertanian. Kata iriagasi berasal dari kata irrigate dalam bahasa Belanda dan irrigation dalam bahasa Inggris. Menurut Abdullah Angoedi (1984) dalam Sejarah Irigasi di Indonesia dalam laporan Pemerintah Belanda irigasi ialah secara teknis menyalurkan air melalui saluran-saluran pembawa ke tanah pertanian dan setelah air tersebut diambil manfaat sebesar-besarnya menyalurkannya ke saluran-saluran pembuangan terus ke sungai.

\section{Ketersediaan Air}

Ketersediaan air adalah jumlah air (debit) yang diperkirakan terus-menerus ada di suatu lokasi (bendung atau bangunan air lainnya) disungai dengan jumlah tertentu dan dalam jangka waktu (periode) tertentu (Anonim, 1986). Ketersediaan air dalam pengertian sumberdaya air pada dasarnya berasal dari air hujan (atmosferik), air permukaan dan air tanah. Hujan yang jatuh di atas permukaan pada suatu Daerah Aliran Sungai (DAS) atau Wilayah Sungai (WS) sebagian akan menguap kembali sesuai dengan proses iklimnya, sebagian akan mengalir melalui permukaan dan sub permukaan masuk ke dalam saluran, sungai atau danau dan sebagian lagi akan meresap jatuh ke tanah sebagai pengisian kembali (recharge) pada air tanah yang ada (Anonim, 2006).

\section{Debit Andalan}

Debit andalan merupakan debit dari suatu sumber air (misal sungai) yang diharapkan dapat disadap untuk keperluan irigasi (SPI KP-1 : 1986). Misalnya ditetapkan debit andalan $80 \%$ berarti akan dihadapi resiko adanya debit-debit yang lebih kecil dari debit andalan sebesar $20 \%$ pengamatan (Soemarto, $C D$ : 1987).

\section{Kebutuhan Air Irigasi}

Kebutuhan air irigasi sebagian besar dicukupi dari air permukaan. Kebutuhan air irigasi ditentukan oleh berbagai faktor seperti cara penyiapan lahan, kebutuhan air untuk tanaman, perkolasi dan rembesan, pergantian lapisan air dan curah hujan efektif. Kebutuhan air irigasi dihitung dengan persamaan (Triatmodjo, 2010).

\section{Kebutuhan Air Konsumtif}

Kebutuhan air untuk tanaman di lahan diartikan sebagai kebutuhan air konsumtif dengan memasukkan faktor koefisien tanaman (kc). Persamaan rumus umum yang digunakan adalah (Triatmodjo, 2010) :

\section{Kebutuhan Air Untuk Penyiapan Lahan}

Kebutuhan air pada waktu persiapan lahan dipengaruhi oleh faktor-faktor antara lain waktu yang diperlukan untuk penyiapan 
lahan (Perhitungan kebutuhan air selama penyiapan lahan $(\mathrm{T})$ dan lapisan air yang dibutuhkan untuk persiapan lahan (S). Perhitungan kebutuhan air selama penyiapan lahan, digunakan metode yang dikembangkan oleh Van de Goor dan Zijlstra (Anonim, 1986).

Kebutuhan Air Untuk Mengganti Lapisan Air (WLR)

Kebutuhan air untuk mengganti lapisan air / Water Layer Requirment (WLR) ditetapkan berdasarkan Standar Perencanaan Irigasi 1986, KP-01. Besar kebutuhan air untuk penggantian lapisan air adalah 50 $\mathrm{mm} /$ bulan (atau 3,3 $\mathrm{mm} /$ hari selama $1 / 2$ bulan) selama satu dan dua bulan setelah transplatasi. Penggantian lapisan air mempunyai tujuan untuk memenuhi kebutuhan air yang terputus akibat kegiatan di sawah. Ketentuan yang berlaku antara lain (Anonim,1986).

\section{Perkolasi ( P )}

Perkolasi adalah proses bergeraknya air melalui profil tanah karena tenaga gravitasi. Air bergerak ke dalam tanah melalui celahcelah dan pori - pori tanah

dan batuan menuju muka air tanah.

Evapotranspirasi

Peristiwa berubahnya air menjadi uap ke udara bergerak dari permukaan tanah, permukaan air dan penguapan melalui tanaman dinamakan evapotranspirasi.

Curah Hujan Andalan

Curah hujan andalan adalah curah hujan rerata daerah minimun untuk kemungkinan terpenuhi yang sudah ditentukan dan dapat dipakai untuk keperluan irigasi. Curah hujan andalan untuk tanaman padi ditetapkan sebesar $80 \%$, sedangkan untuk tanaman palawija sebesar $50 \%$.

\section{Curah Hujan Efektif}

Curah hujan efektif adalah hujan andalan yang jatuh di suatu daerah dan digunakan tanaman untuk pertumbuhan. Curah hujan tersebut merupakan curah

hujan wilayah yang harus diperkirakan dari titik pengamatan yang dinyatakan dalam millimeter (Sosrodarsono, 1980).

\section{Efisiensi Irigasi (EI)}

Efisiensi irigasi merupakan faktor penentu utama dari unjuk kerja suatu sistem jaringan irigasi. Efisiensi irigasi terdiri atas efisiensi pengaliran yang pada umumnya terjadi di jaringan utama dan efisiensi di jaringan sekunder (dari bangunan pembagi sampai petak sawah). Pengertian EI timbul karena terjadi kehilangan air selama proses penyaluran dan pemakaian air irigasi di petak sawah. Jadi EI dapat didefinisikan perbandingan antara jumlah air yg diberikan dikurangi kehilangan air dengan jumlah yang diberikan.

\section{Koefisien Tanaman}

Koefisien tanaman diberikan untuk menghubungkan evapotranspirasi (Eto) dengan evapotranspirasi tanaman acuan (Etc) dan dipakai dalam rumus Penman. Koefisien yang dipakai harus didasarkan pada pengalaman yang terus menerus proyek irigasi di daerah studi. Besarnya nilai suatu Koefisien tanaman tergantung dari umur dan jenis tanaman yang ada. Koefisien tanaman ini merupakan faktor yang dapat digunakan untuk mencari besarnya air yang habis terpakai untuk tanaman untuk masa pertumbuhannya.

Optimasi

Optimasi irigasi telah menjadi pokok dari penelitian selama paling sedikit empat decade, tetapi sejauh ini belum ada prosedur optimasi yang sesuai dan sistimatis yang digunakan dalam rangka produksi pertanian. Analisa menyeluruh di wilayah pertanian umumnya menerapkan teknik-teknik program matematika (mathematical programing) seperti program linier dan program dinamik yaitu pada daerah yang banyak petak dan jenis tanaman, sedangkan jumlah airnya terbatas (Kumar, D.N., et al. 2006).

\section{METODE PENELITIAN}

\section{Rancangan Penelitian}

Beberapa langkah yang dilakukan dalam menyusun tugas akhir ini adalah sebagai berikut

- Mengumpulkan data curah hujan harian selama 10 tahun yang terjadi di Daerah Irigasi Gong Gang.

- Menghitung debit andalan Sungai Gong Gang dalam kurun waktu 10 tahun.

- Mengumpulkan data klimatologi. 
- Menghitung curah hujan efektif untuk masing- masing tanaman.

- Menghitung kebutuhan air untuk masing - masing tanaman.

- Membuat pola tanam

- Mengoptimalkan pola tanam yang sudah di susun dengan bantuan software $Q M$ for Windows 4.

\section{Cara penelitian}

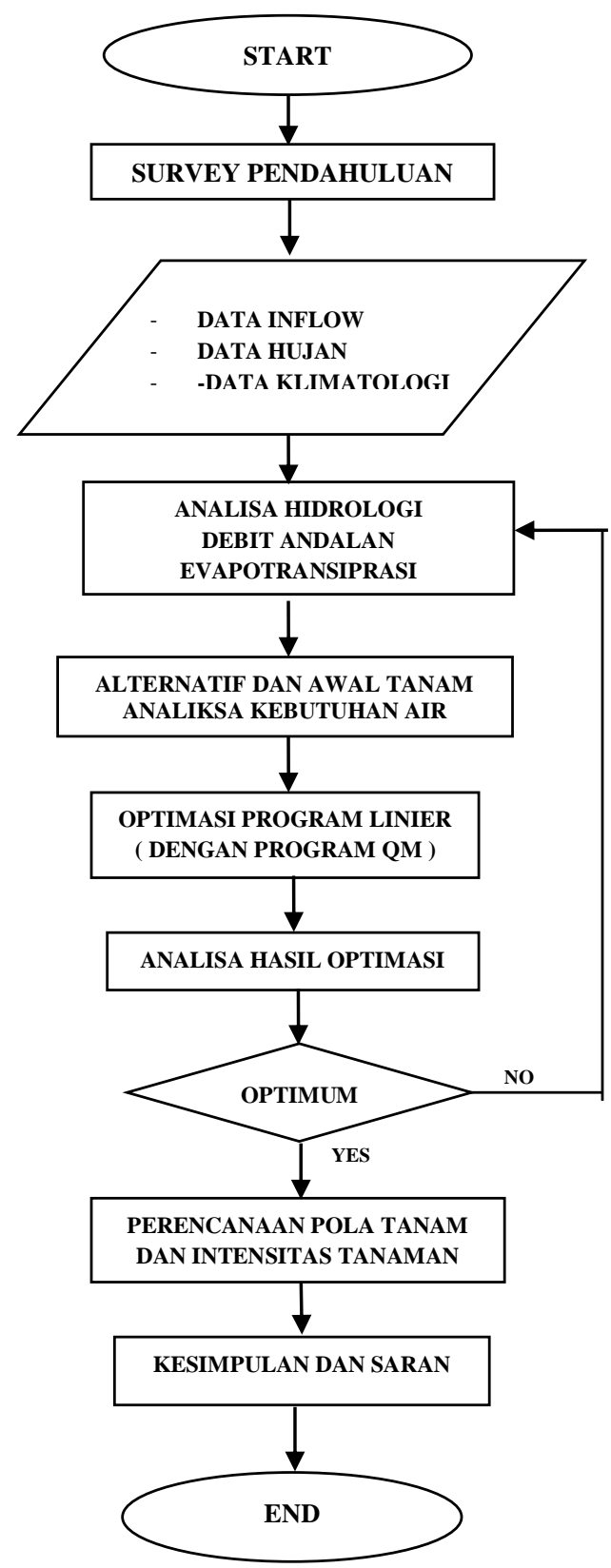

\section{HASIL DAN PEMBAHASAN}

\section{Debit Andalan}

Debit andalan $80 \%$ ialah debit dengan kemungkinan terpenuhi $80 \%$ atau tidak terpenuhi $20 \%$ dari periode waktu tertentu. Untuk menentukan kemungkinan terpenuhi atau tidak terpenuhi, debit yang sudah diamati disusun dengan urutan dari terbesar menuju terkecil. Secara empriris dirumuskan sebagai berikut :

$$
\begin{array}{ll}
\mathrm{m}=0,20 \mathrm{n} \\
\mathrm{ket}: \quad \mathrm{m}=\text { tingkatan tak terpenuhi } \\
\mathrm{n}=\text { jumlah tahun pengamatan }
\end{array}
$$

Contoh Perhitungan untuk data bulan Januari periode pertama :

- Merangking data debit intake bulanan dari yang terbesar sampai yang terkecil dari tahun 2005 sampai dengan tahun 2014

- Menghitung persentase kemungkinan tak terpenuhi

$$
\begin{aligned}
& \mathrm{m}=0,20 \mathrm{n}=>0,2 \times 10=2 \\
& (\text { peringkat } 2 \text { terbawah tak terpenuhi) }
\end{aligned}
$$

Dapat disimpulkan, dari data yang telah diurutkan dari yang terbesar sampai terkecil, karena 2 peringkat terbawah merupakan debit tak terpenuhi, diambil peringkat 3 terbawah sebagai nilai debit andalannya.

Contoh tahapan perhitungan debit andalan metode FJ. Mock untuk Bulan Januari periode 1 ( 15 harian ) tahun 2008

- $\quad$ curah hujan rerata bulanan $(\mathrm{P})=$ $81 \mathrm{~mm} / \mathrm{hari}$

- Jumlah hari hujan (n) = 3hari

- Jumlah hari periode $\quad=15$ hari

- Evapotranspirasi (Ep) $\quad=67,80 \mathrm{~mm} /$ 15 hari

- Besarnya nilai lahan ( $\mathrm{m}$ ) untuk bulan Januari periode satu sebesar $30 \%$ Daerah ladang pertanian, musim kemarau nilai lahan harus di besarkan sekitar 10\% dari musim hujan )

- Koefisien infiltrasi (i) 0,1 tergantung kondisi porositas tanah dan kemiringan daerah pengaliran

- $\quad$ Faktor resesi aliran air $(\mathrm{k})=0,1$

- $\mathrm{AE} / \mathrm{EP}=(\mathrm{m} / 20) \mathrm{x}(18-\mathrm{n})=($ $30 / 20) \times(18-3)=0,23 \%$

- Beda anatara evapotranspirasi potensial dengan evapotranspirasi terbatas

$$
\begin{aligned}
& =\text { Eto } \times(\mathrm{AE} / \mathrm{EP})=467,80 \times 0,23 \\
& =15,26 \mathrm{~mm}
\end{aligned}
$$

- $\mathrm{E}_{\text {actual }}=\mathrm{Et} 0-\mathrm{E}=67,80-15,26=$ $52,55 \mathrm{~mm}$ 
- Water surplus $(\mathrm{WS})=\mathrm{P}-\mathrm{Et}=81-52,55$ $=28,46 \mathrm{~mm} / \mathrm{hari}$

- Infiltrasi (I) $\quad=\mathrm{i} \times \mathrm{WS}=0,1 \mathrm{X}$ $28,46=2,85 \mathrm{~mm} / \mathrm{hari}$

- $0,5 \times(1+\mathrm{k}) \times \mathrm{I}=0,5 \mathrm{X}(1+0,1) 2,85$ $=1,57 \mathrm{~mm} / \mathrm{hari}$

- $\mathrm{K} \times \mathrm{V}(\mathrm{n}-1)=0,1 \times((0,5 \times(1+0,1)$ $43,712+0,74742)=2,47$

- Volume air tanah $(\mathrm{Vn})=(0,5 \times(1+\mathrm{k})$ $\mathrm{x} \mathrm{I})+(\mathrm{K} \mathrm{x} \mathrm{V}(\mathrm{n}-1))=1,57+2,47=4,04$ $\mathrm{mm} / \mathrm{hari}$

- Perubahan volume air tanah $(\mathrm{DVN})=$ $\mathrm{V}_{\mathrm{n}-1}-\mathrm{V}_{\mathrm{n}}=4,04-6,5=-2,46 \mathrm{~mm} / \mathrm{hari}$

- Base flow $(\mathrm{BF})=\mathrm{I}-\mathrm{DVN}=2,85-(-2,46$ ) $=5,31 \mathrm{~mm} / \mathrm{bulan}$

- $\quad$ Direct Run off (DR) $=\mathrm{WS}-\mathrm{I}=28,46-$ $2,85=25,61 \mathrm{~mm} / \mathrm{bln}$

- Aliran Langsung / Run off Balance ( $\mathrm{ROB})=\mathrm{BF}+\mathrm{DR}=5,31+26,61=30,92$ $\mathrm{mm} / \mathrm{hari}$

- $\operatorname{Luas} \operatorname{Das}(\mathrm{A})=191,36 \mathrm{Ha}$

- Debit sungai harian $=\left(\mathrm{A} \times \mathrm{ROB} 1.10^{6}\right.$ )$/\left(1.10^{3} \times\right.$ jumlah hari $\left.\times 24 \times 3600\right)=($ $\left.191,36 \times 30,92 \times 10^{6}\right) /\left(10^{3} \times 15 \times 24 \times\right.$ $3600)=4,56 \mathrm{~m} 3 / \mathrm{dtk}$

\section{Klimatologi dan Evaporasi Potensial}

Berikut contoh perhitungan evaporasi potensial pada bulan Januari

Diketahui data-data pada bulan Januari sebagai berikut :

Lokasi $=60$ Lintang Selatan

Suhu rata-rata $(\mathrm{T})^{\circ} \mathrm{C}=27,13{ }^{\circ} \mathrm{C}$

Kelembaban Relatif $(\%)=75,94 \%$

Lama Penyinaran matahari $(\%)=47,50$ $\%$

Kecepatan angin $(\mathrm{U})=0,84 \mathrm{~km} / \mathrm{jam}=$ $20,16 \mathrm{~km} / \mathrm{hari}$

- Langkah 1 : Mencari harga Tekanan Uap Jenuh (ea) (mbar) Dari data $\mathrm{T}=27,13^{\circ} \mathrm{C}$ , didapat ea $=35,98$ mbar

- Langkah 2 : Mencari harga tekanan uap nyata (ed)(mbar) ed $=$ ea $\times \mathrm{RH}=35,98 \times$ $75,94 \%=27,32 \mathrm{mbar}$

- Langkah 3 : Mencari harga Perbedaan Tekanan Uap air

$($ ea - ed $)($ ea - ed $)=35,98-27,32=8,66$ mbar

- Langkah 4 : Mencari harga fungsi Angin $\mathrm{f}(\mathrm{U})$

$\mathrm{f}(\mathrm{U})=0,27 \times(1+\mathrm{U} / 100)=0,32 \mathrm{~km} / \mathrm{hari}$

- Langkah 5 : Mencari harga faktor (W) dan $(1-W)$
Dari data $\mathrm{T}=27,13^{\circ} \mathrm{C}$, dan ketinggian rata-rata air laut $=0 \mathrm{~m}$, maka didapat $\mathrm{W}$ $=0,76$ dan $(1-\mathrm{W})=0,24$

Langkah 6 : Mencari harga Radiasi extra terrestial ( $\mathrm{Ra}(\mathrm{mm} / \mathrm{hari})$ ) Lokasi berada di $6^{0} \mathrm{LS}$, maka Ra $=15,80 \mathrm{~mm} / \mathrm{hari}$

- Langkah 7 : Mencari harga Radiasi gel. Pendek (Rs)

$\mathrm{Rs}=\left(0,25+0,5^{*}(\mathrm{n} / \mathrm{N})\right) * \mathrm{Ra}=(0,25+$ $0,5(47,50 \%)) 15,80=7,70 \mathrm{~mm} /$ hari

- Langkah 8 : Mencari harga $\mathrm{f}(\mathrm{T})$ koreksi akibat temperature Dari data $\mathrm{T}=$ $27,13^{\circ} \mathrm{C}$, maka didapat $\mathrm{f}(\mathrm{T})=16,19$

- Langkah 9 : Mencari harga f(ed) koreksi akibat tekanan uap nyata

$\mathrm{f}(\mathrm{ed})=0,34-0,044 \sqrt{ } \mathrm{ed}=0,34-$ $0,044 \sqrt{ } 27,32=0,11$

- Langkah 10 : Mencari harga $\mathrm{f}(\mathrm{n} / \mathrm{N})$ $\mathrm{f}(\mathrm{n} / \mathrm{N})=(0,1+0,9 *(\mathrm{n} / \mathrm{N}))=0,1+$ $0,9(47,50 \%)=0,53$

- Langkah 11 : Mencari harga Radiasi netto Gelombang. Panjang (Rn1)

$\mathrm{Rn} 1=\mathrm{f}(\mathrm{T}) * \mathrm{f}(\mathrm{ed}) * \mathrm{f}(\mathrm{n} / \mathrm{N})=16,19 * 0,11$ $* 0,53=0,94 \mathrm{~mm} / \mathrm{hari}$

- Langkah 12 : Mencari harga Netto Gelombang Pendek (Rns)

Rns $=\operatorname{Rs}(1-\alpha)=7,70 *(1-0,25)=5,78$ $\mathrm{mm} / \mathrm{hari}$

- Langkah 13 : Mencari harga Radiasi netto (Rn)

$\mathrm{Rn}=\mathrm{Rns}-\mathrm{Rn} 1=5,78-0,94=4,84$ $\mathrm{mm} / \mathrm{hari}$

- Langkah 14 : Mencari harga Faktor koreksi $(\mathrm{c})=1,04$

Eto $\quad=\mathrm{c}\{\mathrm{W} \cdot \mathrm{Rn}+(1-\mathrm{W}) . \mathrm{f}(\mathrm{u})$. (ea - ed) $\}=1,04\{0,76 \cdot 4,84+(0,24)$. $(0,32)$. $(8,66)\}=4,52 \mathrm{~mm} / \mathrm{hari}$

\section{Curah Hujan Efektif}

Turunnya curah hujan pada suatu areal lahan mempengaruhi pertumbuhan tanaman di areal tersebut. Curah hujan tersebut dapat dimanfaatkan oleh tanaman untuk mengganti kehilangan air yang terjadi akibat evapotranspirasi, perkolasi, kebutuhan pengolahan tanah dan penyiapan lahan. Curah hujan efektif merupakan curah hujan yang jatuh pada suatu daerah dan dapat digunakan tanaman untuk pertumbuhannya. Jumlah hujan yang dapat dimanfaatkan oleh tanaman tergantung pada jenis tanaman. Curah hujan efektif juga dapat dihitung berdasarkan data hujan yang tersedia dengan peluang keandalan 
$80 \%$. Data berasal dari data curah hujan yang tercatat di stasiun hujan yang berdekatan / berada dalam cakupan areal irigasi tersebut. Data curah hujan harian yang tersedia ialah data hujan harian dari tahun 2006 sampai dengan tahun 2014 dari stasiun hujan GongGang. Data tersebut kemudian direkap menjadi data hujan 10 harian, setelah memperoleh data hujan periode 10 harian tersebut untuk masing - masing stasiun hujan selanjutnya dilakukan perhitungan curah hujan rata-rata. Salah satu cara perhitungan curah hujan rata-rata ini ialah dengan menggunakan rumus cara rata-rata aljabar dengan alasan, bahwa cara ini ialah obyektif yang berbeda dengan cara isohyet, dimana faktor subjektif turut menentukan (Sosrodarsono, Suyono : 1985).

Untuk perhitungan bulan dan tahun yang lain direkap dalam tabel 4.5. Setelah nilai hujan rata-rata diperoleh langkah selanjutnya ialah tahap perhitungan curah hujan efektif. Proses perhitungannya ialah sebagai berikut :

Contoh Perhitungan Curah Hujan Efektif Tahapan yang dilakukan sebagai berikut :

- Menghitung curah hujan rata - rata (tabel 4.5).

- Urutkan hasil hujan rata-rata tiap tahunnya dari urutan yang besar sampai yang terkecil.

- Menghitung $\mathrm{R} 80=(\mathrm{n} / 5)+1$, dimana $\mathrm{n}=$ Jumlah data $=10$, maka R80 $=(10 / 5)+$ $1=3$

- Dari 10 data hujan rata-rata yang telah diurutkan tersebu diambil urutan ke-3 dari urutan terkecil sebagai curah hujan R80 nya

- Menghitung Re masing-masing tanaman dengan rumus :

Re padi $=(\operatorname{R} 80 \times 70 \%) / 10 \mathrm{~mm} / \mathrm{hari}$

$\operatorname{Re} t e b u=(\mathrm{R} 80 \times 60 \%) / 10 \mathrm{~mm} / \mathrm{hari}$

$\operatorname{Re}$ polowijo $=(\operatorname{R80} \times 50 \%) / 10 \mathrm{~mm} / \mathrm{hari}$

\section{Pengolahan tanah dan penyiapan lahan}

Faktor ini merupakan langkah pertama yang dibutuhkan oleh tanaman dalam mempersiapkan tanahnya untuk penanaman. Setiap jenis tanaman membutuhkan pengolahan tanah yang berbedabeda. Pengolahan tanah untuk padi membutuhkan air irigasi yang lebih banyak, karena padi akan memerlukan tanah dengan tingkat kejenuhan yang baik dan dalam keadaan tanah yang lunak dan gembur. Pengolahan tanah ini dilakukan antara 20 sampai dengan 30 hari sebelum masa tanam. Minggu pertama sebelum kegiatan penanaman dimulai, petak sawah diberi air secukupnya untuk melunakkan tanahnya. Biasanya dilakukan dengan membajak atau mencangkul sawah. Kebutuhan air untuk pengolahan tanah dipengaruhi oleh proses evapotranspirasi potensial yang terjadi.

$$
\mathrm{LP}=\mathrm{M} \text {. ek / }(\mathrm{ek}-1)
$$

Berikut contoh perhitungan pada bulan Januari :

$$
\begin{aligned}
& \text { Eo }=\text { ETo } \times 1,10=4,52 \times 1,10=4,972 \\
& \text { mm/hari } \\
& \mathrm{P}=2 \mathrm{~mm} / \text { hari } \\
& \mathrm{M}=\mathrm{Eo}+\mathrm{P}=7,972 \mathrm{~mm} / \mathrm{hari}
\end{aligned}
$$

\section{Model Matematika Optimasi}

Untuk memperoleh hasil yang efektif, dengan maksud mendekati kondisi kenyataan yang ada dengan metode yang dipakai maka analisa ini dilakukan dengan mengambil batasan yang mengacu pada persyaratan sesuai kondisi di lapangan sebagai berikut :

- Daerah Irigasi Gonggang seluas 2386 Ha, dianggap sebagian besar ditanami padi dengan luas maximum $1990 \mathrm{Ha}$ sesuai dengan kondisi eksisting dan sebagian kecil ditanami jagung dan tebu.

- Untuk ketersediaan air yang akan digunakan untuk mengoptimasi luas lahan ialah dengan menjumlahkan volume andalan sungai sesuai dengan musim tanam sebagai berikut

- Kebutuhan air untuk irigasi tidak boleh melebihi kapasitas intake bendung. Kapasitas intake bendung Gonggang dianggap sama dengan debit intake minimum yaitu $=45.950 .980 \mathrm{~m}^{3} / \mathrm{musim}$.

- Model yang digunakan sebagai berikut : Maximumkan :

$\mathrm{Z}=\mathrm{A} \cdot \mathrm{X} 1 \mathrm{a}+\mathrm{B} \cdot \mathrm{X} 1 \mathrm{~b}+0 . \mathrm{X} 1 \mathrm{c}+\mathrm{A} \cdot \mathrm{X} 2 \mathrm{a}+$ B.X2b + 0.X2c + A.X3a + B.X3b + C.X3c, dimana:

$\mathrm{Z}=$ Nilai tujuan yang akan dicapai ( maximumkan keuntungan ( $\mathrm{Rp})$ )

$\mathrm{A}=$ Pendapatan produksi padi $(\mathrm{Rp} / \mathrm{Ha})$

$\mathrm{B}=$ Pendapatan produksi polowijo (Rp/Ha)

$\mathrm{C}=$ Pendapatan produksi tebu $(\mathrm{Rp} / \mathrm{Ha})$

$\mathrm{X} 1 \mathrm{a}=$ Luasan areal tanam padi musim Hujan (Ha) 
$\mathrm{X} 1 \mathrm{~b}=$ Luasan areal tanam polowijo musim Hujan (Ha)

$\mathrm{X} 1 \mathrm{c}=$ Luasan areal tanam tebu musim Hujan (Ha)

$\mathrm{X} 2 \mathrm{a}=$ Luasan areal tanam padi musim Kemarau I(Ha)

$\mathrm{X} 2 \mathrm{~b}=$ Luasan areal tanam polowijo musim Kemarau I (Ha)

$\mathrm{X} 2 \mathrm{c}=$ Luasan areal tanam tebu musim Kemarau I (Ha)

$\mathrm{X} 3 \mathrm{a}=$ Luasan areal tanam padi musim KemarauII (Ha)

$\mathrm{X} 3 \mathrm{~b}=$ Luasan areal tanam polowijo musim Kemarau II (Ha)

$\mathrm{X} 3 \mathrm{c}=$ Luasan areal tanam tebu musim Kemarau II (Ha)

- Fungsi batasan yang digunakan sebagai berikut :

Luas Maksimum:

$\mathrm{X} 1 \mathrm{a}+\mathrm{X} 1 \mathrm{~b}+\mathrm{X} 1 \mathrm{c} \leq \mathrm{Xt}$

$X 2 a+X 2 b+X 2 c \leq X t$

$\mathrm{X} 3 \mathrm{a}+\mathrm{X} 3 \mathrm{~b}+\mathrm{X} 3 \mathrm{c} \leq \mathrm{Xt}$

Keterangan :

$\mathrm{Xt}=$ Luasa total daerah irigasi Gonggang $(=2386 \mathrm{Ha})$

Volume Andalan Sungai :

Vp1.X1a + Vj1.X1b + Vt1.X1c $\leq$ Vs1

$\mathrm{Vp2} . \mathrm{X} 2 \mathrm{a}+\mathrm{Vj} 2 . \mathrm{X} 2 \mathrm{~b}+\mathrm{Vt} 2 . \mathrm{X} 2 \mathrm{c} \leq \mathrm{Vs} 2$

$\mathrm{Vp3} . \mathrm{X} 3 \mathrm{a}+\mathrm{Vj} 3 . \mathrm{X} 3 \mathrm{~b}+\mathrm{Vt3} . \mathrm{X} 3 \mathrm{c} \leq \mathrm{Vs} 3$

Keterangan :

Vpi $=$ Kebutuhan air padi tiap musim (Lampiran )

$\mathrm{Vji}=$ Kebutuhan air palawija tiap musim (Lampiran )

Vti = Kebutuhan air tebu tiap musim (Lampiran)

Vs1 = Volume andalan sungai pada musim Hujan $=94.893 .120 \mathrm{~m}^{3}$

Vs2 = Volume andalan sungai pada musim Kemarau I $=56.261 .150 \mathrm{~m}^{3}$

Vs3 = Volume andalan sungai pada musim Kemarau II $=18.052 .960 \mathrm{~m}^{3}$

Tanaman Padi :

$\mathrm{X} 1 \mathrm{a} \leq \mathrm{Xpa}$

$\mathrm{X} 2 \mathrm{a} \leq \mathrm{Xpa}$

$\mathrm{X} 3 \mathrm{a} \leq \mathrm{Xpa}$

$\mathrm{X} 1 \mathrm{c} \geq \mathrm{Xte}$

$X 2 c \geq X$ te

$\mathrm{X} 3 \mathrm{c} \geq \mathrm{Xte}$

$\mathrm{X} 1 \mathrm{c}-\mathrm{X} 2 \mathrm{c}=0$

$\mathrm{X} 2 \mathrm{c}-\mathrm{X} 3 \mathrm{c}=0$

Keterangan :

$\mathrm{Xpa}=$ Luas maximum tanaman padi yang disyaratkan (= $1990 \mathrm{Ha})$
Xte $=$ Luas minimum tanaman tebu yang disyaratkan ( = $89 \mathrm{Ha})$

Kapasitas Intake

$\mathrm{Vp1.X1a}+\mathrm{Vj} 1 . \mathrm{X} 1 \mathrm{~b}+\mathrm{Vt1} . \mathrm{X} 1 \mathrm{c} \leq \mathrm{Qb}$

$\mathrm{Vp} 2 . X 2 \mathrm{a}+\mathrm{Vj} 2 . \mathrm{X} 2 \mathrm{~b}+\mathrm{Vt} 2 . \mathrm{X} 2 \mathrm{c} \leq \mathrm{Qb}$

$\mathrm{Vp} 3 . X 3 \mathrm{a}+\mathrm{Vj} 3 . \mathrm{X} 3 \mathrm{~b}+\mathrm{Vt} 3 . \mathrm{X} 3 \mathrm{c} \leq \mathrm{Qb}$

Keterangan :

$\mathrm{Qb}=$ Kapasitas Intake $\left(=45.950 .976 \mathrm{~m}^{3}\right)$

(Contoh perhitungan untuk awal tanam nopember I)

Maksimumkan

$\mathrm{Z}=14840750 . X 1 \mathrm{a}+9312000 . \mathrm{X} 1 \mathrm{~b}+$

$814700 . \mathrm{X} 1 \mathrm{c}+14840750 . \mathrm{X} 2 \mathrm{a}+$

9312000.X2b + 8147000.X2c +

14840750.X3a $+9312000 . X 3 \mathrm{~b}+$ 8147000.X3c

Persamaan Kendala :

- $16.943,04$ X1a + 4415,04 X1b + 3870,72 $\mathrm{X} 1 \mathrm{c} \leq 94.983 .120$

- $\quad 18.083,52 \mathrm{X} 2 \mathrm{a}+7732,2 \mathrm{X} 2 \mathrm{~b}+4933,44$ $\mathrm{X} 2 \mathrm{c} \leq 56.261 .152$

- $16718,4 \times 3 a+6523,2 X 3 b+4898,88$ $\mathrm{X} 3 \mathrm{c} \leq 18.052 .956$

- $\quad 16.943,04 \times 1 a+4415,04$ X1b +3870,72 $\mathrm{X} 1 \mathrm{c} \leq 45.950 .976$

- $\quad 18.083,52$ X2a + 7732,2 X2b + 4933,44 $\mathrm{X} 2 \mathrm{c} \leq 45.950 .976$

- $16.718,4 \mathrm{X3a}+6523,2 \mathrm{X} 3 \mathrm{~b}+$ $4898,88 \times 3 c \leq 45.950 .976$

- X1a, X1b, X1c, X2a, X2b, X2c, X3a, $\mathrm{X} 3 \mathrm{~b}, \mathrm{X} 3 \mathrm{c} \geq 0$

Selanjutnya, persamaan -persamaan tersebut dimasukkan kedalam tabel simpleks untuk dilakukan iterasi. Sebagai alat bantu penyelesaian optimasi tersebut dapat juga dilakukan dengan menggunakan program bantu QM for Windows 2.

Dari hasil perhitungan linear programming tersebut diperoleh solusi optimum sebagai berikut :

Padi MH = 1990 ha

Polowijo $\mathrm{MH}=307$ ha

Tebu $\mathrm{MH}=89$ ha

Padi MKI $=1990$ ha

Polowijo MKI = 307 ha

Tebu MKI = 89 ha

Padi MKII $=258,27 \mathrm{ha}$

Polowijo MKII $=2.038,725$ ha

Tebu MKII = 89 ha

Dari nilai luasan masing - masing tanaman yang sebelumnya dihitung dengan $Q M$ for 
Windows tersebut dimasukkan ke persamaan tujuan maksimumkan

$\begin{array}{llll}Z=14840750 . X 1 \mathrm{a} & +9312000 . X 1 \mathrm{~b} & + \\ 8147000 . \mathrm{X} 1 \mathrm{c}+ & 14840750 . X 2 \mathrm{a} & + \\ 9312000 . \mathrm{X} 2 \mathrm{~b} & + & 8147000 . X 2 \mathrm{c} & + \\ 14840750 . X 3 \mathrm{a} & + & 9312000 . X 3 \mathrm{~b} & + \\ 8147000 . X 3 \mathrm{c} & & & \end{array}$

Sehingga dapat dihasilkan keuntungan produksi tanam sebesar $=$

Rp 106.729.700.000

Dari hasil optimasi diatas, didapat pola tanam sebagai berikut :

- Musim Hujan : Padi/Palawija/Tebu

- Musim Kemarau I : Padi/Palawija/Tebu

- Musim Kemarau II : Padi/Palawija/Tebu Sehingga pola tanam Nopember II = Padi/Palawija/Tebu- Padi/Palawija/Tebu Padi/Palawija/Tebu

\section{KESIMPULAN DAN SARAN}

\section{Kesimpulan}

Beberapa kesimpulan yang dapat diambil dari pembahasan pada bab sebelumnya, antara lain:

- Dari data debit sungai Gonggang,dengan menggunakan perumusan empiris diperoleh debit andalan sungai dengan peluang keandalan $80 \%$ (Q80\%).

- Dalam studi ini telah dicoba 4 alternatif awal tanam (Nopember I, Nopember II, Desember I dan Desember II). Dari alternatif-alternatif tersebut,dilakukan perhitungan kebutuhan air untuk tiap tanaman (padi, palawija dan tebu).

- Berdasarkan kebutuhan air dan debit andalan yang ada, telah dilakukan perhitungan untuk mencari luasan yang optimal dari tiap alternatif awal tanam. Dengan menggunakan program bantu Quantity Methods for Windows 4 telah diperoleh luasan tiap tanaman yang dapat diairi selama 1 tahun sesuai dengan alternatif awal tanamnya masing-masing. Dari tabel 4.17 dapat dilihat besarnya luasan tanam dari tiap-tiap alternatif awal tanam. Luasan areal tanam yang dapat dilayani secara optimum adalah sebesar 7158 ha dengan intensitas tanam sebesar ialah $300 \%$ dengan masa awal tanam dimulai pada bulan Nopember dekade I.
- Keuntungan maksimum hasil usaha tani yang akan diperoleh selama setahun berdasarkan luasan optimalnya ialah sebesar Rp 106.729.700.000,- dengan pola tanam padi/palawija/tebupadi/palawija/tebu- padi / palawija/tebu selama 1 tahun.

\section{Saran}

Adapun saran yang bisa diberikan berdasarkan hasil kesimpulan studi yang telah diperoleh antara lain sebagai berikut :

- Jika pola tanam hasil optimasi ini ingin diterapkan, pihak terkait, dalam hal ini adalah Balai PSAWS (Pengelolaan Sumber Daya Air Wilayah Sungai) Gong Gang - Magetan sebaiknya melakukan pendekatan terlebih dahulu kepada petani untuk mendapat persetujuan petani terkait perubahan pola tanam tersebut.

- Balai PSAWS Gong Gang - Magetan hendaknya juga memperhatikan dan meningkatkan pengelolaan dan pemeliharaan di lapangan seperti bangunan air dan saluran yang selama ini kurang diperhatikan karena dapat menghambat dan memperbesar kebutuhan air selama diperjalanan.

- Untuk mengetahui apakah hasil yang dicapai sudah benar-benar optimal, disarankan kepada mahasiswa lain yang ingin memperdalam lagi subjek ini untuk mencoba berbagai alternatif pola tanam yang lain dan dicocokkan dengan data kondisi lapangan yang terbaru

\section{DAFTAR PUSTAKA}

Kementerian Pekerjaan Umum. 2010. Kebijakan Umum, Teknis dan Perundang-undangan Bidang SDA. Surabaya : Kementrian PekerjaanUmum Pusat Pendidikan dan Pelatihan.

Pengolahan SDA terpadu. Surabaya : Kementrian Pekerjaan Umum Pusat Pendidikan dan Pelatihan.

Undang-undang RI Nomor 7/2004 Tentang SDA, Penjelasan Tentang Undangundang RI Nomor 7/2004, PP Nomor 20/2006 Tentang Irigasi. Surabaya : Kementrian Pekerjaan Umum Pusat Pendidikan dan Pelatihan. 
Dasar-dasar Umum Pelaksanaan Pengolaan

Sumber Daya Air. Surabaya : Kementrian Pekerjaan Umum Pusat Pendidikan dan Pelatihan.

Linsei Ray K dan Franzini Joseph . 1991, Teknik Sumber Daya Air, Erlangga, Surabaya

Sudjarwadi. 1987. Dasar Dasar Teknik Irigasi, Universitas Gajah Mada, Yogyakarta.

Pasandara effendi dan C. Taylor Donald. 1984 IRIGASI Perencanaan dan Pengelolaan, Gramadia, Jakarta 